Tropical Journal of Pharmaceutical Research November 2017; 16 (11): 2681-2688

ISSN: $1596-5996$ (print); 1596-9827 (electronic)

(c) Pharmacotherapy Group, Faculty of Pharmacy, University of Benin, Benin City, 300001 Nigeria.

All rights reserved.

Available online at http://www.tjpr.org

Original Research Article

http://dx.doi.org/10.4314/tjpr.v16i11.16

\title{
Inhibitory effects of total saponins from Ilex pubescens Hook against hydrogen peroxide-induced cardiomyocyte apoptosis
}

\author{
Ming-zhong Ying, Jian-jun Wu, Jian-min Yin, Xue-qin Shen and Fan Li ${ }^{\star}$ \\ The International Medical Center of the Chinese PLA General Hospital, Beijing 100853, China
}

${ }^{\star}$ For correspondence: Email: lifanpla@126.com

Sent for review: 5 May 2017

Revised accepted: 10 October 2017

\begin{abstract}
Purpose: To study the protective effects of total saponins from llex pubescens Hook (IPTS) against cardiomyocyte apoptosis.

Methods: Response surface methodology (RSM) based on Box-Benhnken Design (BBD) was carried out to optimize the extraction of IPTS. Thereafter, H9c2 cell model prepared by hydrogen peroxide $\left(\mathrm{H}_{2} \mathrm{O}_{2}\right)$ treatment was used to investigate the effects of IPTS on cardiomyocyte apoptosis. Cell viability was determined using MTT assay, while the levels of lactate dehydrogenase (LDH), malondialdehyde $(M D A)$, superoxide dismutase (SOD), creatine kinase (CK) and catalase (CAT) were measured as indices of oxidative stress. Expressions of proteins related to apoptosis (caspase-3, Bax and Bcl-2) were measured using Western blot assay.

Results: Optimal IPTS extraction was achieved with extraction temperature of $86.6{ }^{\circ} \mathrm{C}$, extraction time of $2.23 \mathrm{~h}$ and water: raw material ratio of $10.8 \mathrm{~mL} / \mathrm{g}$. IPTS extract, at doses of 200, 400, 600 and 800 $\mu \mathrm{g} / \mathrm{mL}$, significantly increased the viability of $\mathrm{H}_{2} \mathrm{O}_{2}$-treated $\mathrm{H} 9 \mathrm{c} 2$ cells $(p<0.05)$, but significantly decreased LDH and CK activities $(p<0.01)$. It also led to significant increases in SOD and CAT activities, and significant decreases in the levels of MDA in these cells $(p<0.01)$. There were significant down-regulation of the protein expressions of caspase-3 and Bax $(p<0.01)$ in IPTS-treated H9c2 cells, as well as significant up-regulation of $B c-2$ protein expression $(p<0.01)$.

Conclusion: These results suggest that IPTS can protect cardiomyocytes against apoptosis via the inhibition of oxidative stress and mitochondria-induced intrinsic apoptosis.
\end{abstract}

Keywords: Ilex pubescens, Total saponins, Cardiomyocytes, Apoptosis, H9c2 cells

Tropical Journal of Pharmaceutical Research is indexed by Science Citation Index (SciSearch), Scopus, International Pharmaceutical Abstract, Chemical Abstracts, Embase, Index Copernicus, EBSCO, African Index Medicus, JournalSeek, Journal Citation Reports/Science Edition, Directory of Open Access Journals (DOAJ), African Journal Online, Bioline International, Open-J-Gate and Pharmacy Abstracts

\section{INTRODUCTION}

With the rapid development of social economy, the incidence of cardiovascular disease is rising year by year. And in China, cardiovascular disease has been ranked second only to malignant tumors, amongst the killer diseases [1]. Excessive superoxide anion is considered one of the main factors involved in the etiology of cardiovascular disease; it can neutralize nitric oxide and cause endothelial dysfunction [1]. In addition, a number of studies have shown that oxidative stress is a common mechanism of cardiovascular injury caused by many pathological factors [2]. The increased level of ROS in many cardiovascular diseases could lead to lipid and protein peroxidation, irreversible cell damage and DNA damage $[3,4]$.

Ilex pubescens (IP) Hook is used as a popular folk medicine in southern area of China, for treating coronary heart disease, angina and 
myocardial infarction [5]. Studies on the phytochemical composition of IP show that it is rich in saponins, flavones and phenylpropanoid compounds [6]. Saponins possess significant anti-coagulation and anti-thrombotic properties [7]. However, to date, there are no studies on the effects of total saponins from IP on myocardial function. Thus, the current study was aimed at investigating the protective effects of total saponins from llex pubescens (IPTS) against apoptosis in myocardial cells, and its underlying mechanism, using $\mathrm{H}_{2} \mathrm{O}_{2}$-treated cardiomyocyte $\mathrm{H} 9 \mathrm{c} 2$ cell line model.

\section{EXPERIMENTAL}

\section{Cells culture}

The cardiomyoblast $\mathrm{H} 9 \mathrm{c} 2$ cell line was obtained from Cell Bank of Chinese Academy of Sciences (Shanghai, China). The cells were maintained in $90 \%$ Dulbecco's modified Eagle's medium (DMEM) with $10 \%$ heat-inactivated fetal bovine serum (FBS) and antibiotics ( $1 \%$ penicillin and streptomycin). The cells were incubated in an incubator with $5 \% \mathrm{CO}_{2}$ and $95 \%$ humidity at 37 ${ }^{\circ} \mathrm{C}$.

\section{Chemicals}

Ilex saponin B1 was purchased from Shanghai biochemical reagent Co., Ltd. (Shanghai, China). Methyl-thiazdyldiphenyl-tetrazolium bromide (MTT), $\mathrm{H}_{2} \mathrm{O}_{2}$ and dimethyl sulfoxide (DMSO) were products of Sigma-Aldrich Co. (St. Louis, MO, USA). The DMEM media and FBS were obtained from Gibco Co. (Grand Island, NY, USA). LDH, MDA, SOD, CK and CAT assay kits were obtained from the Jiancheng Bioengineering Institute (Nanjing, China). IP Cell Lysis Buffer, BCA Protein Assay Kit, and Caspase-3, Bcl-2 and Bax monoclonal primary antibodies were obtained from the Beyo time Co. (Haimen, China). All other chemicals used in this study were of analytical reagent grade.

\section{Preparation of LPTS}

Ilex pubescens (IP) was purchased from Bozhou Chinese herbal medicine market (Anhui, China) in August 2014, and authenticated at the International Medical Center of the Chinese PLA General Hospital. A voucher specimen (PLA no. 2014-119) was deposited in the herbarium of the Department. Dried LP was processed to powder and exhaustively extracted with $50 \%$ ethanol by hot reflux. The extract was concentrated, dried at $50{ }^{\circ} \mathrm{C}$, dissolved with distilled water and re- extracted with ether and water-saturated butanol. The resultant extract was evaporated under vacuum, and dried at $50{ }^{\circ} \mathrm{C}$ to obtain the crude IPTS. The crude IPTS was dissolved in distilled water, and purified using the macro porous adsorption resin method [8].

The IPTS content was determined by vanillinperchloric-acid method, with llex saponin B1 as standard [8]. The relationship between absorbance and concentration can be expressed as $A=0.00315 C+0.0079(R=0.9920)$, where $A=$ absorbance, and $\mathrm{C}=$ concentration. The LPTS yield (\%) was calculated from this equation.

\section{Experimental design and statistical analysis}

Results of previous single factor experiments showed that the major factors which influence the extraction of IPTS were extraction temperature $(A)$, extraction time $(B)$ and ratio of water to raw material $(\mathrm{C})$. To obtain optimal extraction of IPTS, RSM based on BBD was used in the present studies. As shown in Table 1, seventeen experiments were performed in random order.

All the tests were replicated three times, and analysis of variance (ANOVA) was used to analysis the BBD results. Design Expert (version 8.0.6, Stat-Ease, Inc., Minneapolis, MN, USA) software was used to estimate the response of independent variables. Response surfaces were obtained to determine the individual and interactive effects of the experimental variable. Subsequently, additional confirmatory experiments were carried out to verify the validity of the statistical experimental design.

\section{MTT assay}

3-(4,5-dimethylthiazol-2-yl)-2,5-diphenyl

tetrazolium (MTT) assay was carried out to determine cell viability according to the method reported previously[9]. The H9c2 cells $(5 \times$ $10^{4} / 0.2 \mathrm{~mL}$ ) were seeded in 96 -well plates and treated with LPTS $(100,200,400,600$ and 800 $\mu \mathrm{g} / \mathrm{mL})$ with the presence of $\mathrm{H}_{2} \mathrm{O}_{2}(100 \mu \mathrm{mo} 1 / \mathrm{L})$ for $24 \mathrm{~h}$ at $37^{\circ} \mathrm{C}$ [10]. Absorbance (A) was measured at $570 \mathrm{~nm}$ using a 96-well plate reader (BioTek Instruments, Inc, Burlington, VT, USA). Cell viability (V) was calculated using Eq 1.

$V(\%)=(A t / A c) 100$

where At and Ac are the absorbance values of treated and control samples respectively. 
Table 1: BBD experimental design with the independent variables

\begin{tabular}{|c|c|c|c|c|}
\hline Run & $A\left({ }^{\circ} \mathrm{C}\right)$ & B (h) & $\mathbf{C}$ & Yield (\%) \\
\hline 1 & 60.00 & 1.00 & 10.00 & 3.41 \\
\hline 2 & 100.00 & 3.00 & 10.00 & 5.36 \\
\hline 3 & 80.00 & 1.00 & 15.00 & 4.79 \\
\hline 4 & 80.00 & 2.00 & 10.00 & 6.06 \\
\hline 5 & 60.00 & 2.00 & 5.00 & 4.08 \\
\hline 6 & 100.00 & 2.00 & 15.00 & 5.12 \\
\hline 7 & 80.00 & 2.00 & 10.00 & 5.98 \\
\hline 8 & 60.00 & 2.00 & 15.00 & 3.63 \\
\hline 9 & 80.00 & 2.00 & 10.00 & 5.79 \\
\hline 10 & 100.00 & 1.00 & 10.00 & 4.14 \\
\hline 11 & 80.00 & 2.00 & 10.00 & 6.09 \\
\hline 12 & 80.00 & 2.00 & 10.00 & 5.86 \\
\hline 13 & 80.00 & 3.00 & 5.00 & 4.76 \\
\hline 14 & 100.00 & 2.00 & 5.00 & 4.78 \\
\hline 15 & 60.00 & 3.00 & 10.00 & 3.52 \\
\hline 16 & 80.00 & 3.00 & 15.00 & 5.04 \\
\hline 17 & 80.00 & 1.00 & 5.00 & 4.01 \\
\hline
\end{tabular}

Note: BBD = Box-Behnken Design

\section{Determination of LDH, CK, SOD, CAT and MDA in $\mathrm{H} 9 \mathrm{c2}$ cells}

After $24 \mathrm{~h}$ of treatment, supernatants from the $\mathrm{H} 9 \mathrm{c} 2$ cells were collected for the assay of LDH and CK activities using commercial kits according to the manufacture's instruction. Subsequently, total proteins were extracted from the H9c2 cells with IP cell lysis buffer. Then protein concentration was determined using a BCA protein assay kit. The contents of SOD, CAT and MDA were determined with commercial kits.

\section{Western blot analysis}

Proteins were extracted from the H9c2 cells treated with IPTS $(200,400$ and $800 \mu \mathrm{g} / \mathrm{mL})$ were extracted with IP cell lysis buffer, and protein concentration was measured using BCA protein assay kit. Equal amounts of cell proteins $(35 \mu \mathrm{g})$ were separated by $12 \%$ sodium dodecyl sulfate-polyacrylamide gel electrophoresis (SDSPAGE), transferred to polyvinyl idene difluoride (PVDF) membrane and probed with various primary antibodies (caspase-3,Bax and Bcl-2). The resultant protein bands were detected after incubating with secondary antibodies and visualized by enhanced chemiluminescence reagent (Pierce-ECL western blotting substrate, Thermo Scientific). To normalize for protein loading, antibodies directed against GAPDH were used. In addition, immune blotting signals were quantitated using a Bio-Rad Chemi Doc XRS gel imaging system (Hercules, CA, USA).

\section{Statistical analysis}

All data are presented as mean \pm standard deviation (SD). The RSM data analysis was performed by using Design Expert Version 8.0.6 software (Stat-Ease, Inc., USA). Group comparison was performed by ANOVA (SPSS 16.0, SPSS Inc., USA). Statistical significance was assumed at $p<0.05$.

\section{RESULTS}

\section{RSM data}

Multiple regression analysis of the experimental data revealed the predicted response $Y$ (extraction yield of IPTS, \%) could be obtained from the second-order polynomial equation:

$Y=-165.936+0.401 A+2.633 B+0.320 C+$ $0.014 A B+0.002 A C-0.025 B C-0.003 A^{2}-$ $0.801 B^{2}-0.020 C^{2}$

The results of response surface analysis are shown in Table 2 and Figure 1. The determination coefficient $\left(R^{2}=0.9804\right)$ and the adjusted determination coefficient $\left(R^{2}\right.$ adj $=$ 0.9551) showed a high degree of correlation between the observed and predicted values. The experiment possessed a very low $p$-value (0.0001) and a very high $F$-value $(F=38.85)$, which showed that the proposed model was highly significant. In addition, F-value (4.09) and $p$-value (0.1036) of lack-of-fit showed that it was not significant relative to the pure error, indicating that the model equation was adequate for predicting the IPTS yield under any combination of variables values.

The 2D contour plots and the 3D response surface were presented on Figure 1, which indicated the effects of independent variables and mutual interaction on the IPTS yield. 
Table 2: Analysis of variance (ANOVA) data obtained from BBD

\begin{tabular}{|c|c|c|c|c|c|c|c|}
\hline Source & & Sum of squares & df & Mean square & & $F$-value & $P$-value \\
\hline Model & & 13.43 & 9 & 1.49 & & 38.85 & $<0.0001$ \\
\hline A & & 2.83 & 1 & 2.83 & & 73.73 & $<0.0001$ \\
\hline B & & 0.68 & 1 & 0.68 & & 17.67 & 0.0040 \\
\hline C & & 0.11 & 1 & 0.11 & & 2.94 & 0.1303 \\
\hline$A B$ & & 0.31 & 1 & 0.31 & & 8.02 & 0.0253 \\
\hline$A C$ & & 0.16 & 1 & 0.16 & & 4.06 & 0.0837 \\
\hline$B C$ & & 0.063 & 1 & 0.063 & & 1.63 & 0.2428 \\
\hline$A^{2}$ & & 4.62 & 1 & 4.62 & & 120.39 & $<0.0001$ \\
\hline $\mathrm{B}^{2}$ & & 2.70 & 1 & 2.70 & & 70.24 & $<0.0001$ \\
\hline$c^{2}$ & & 1.08 & 1 & 1.08 & & 28.01 & 0.0011 \\
\hline Residual & & 0.27 & 7 & 0.038 & & & \\
\hline Lack of fit & & 0.20 & 3 & 0.068 & & 4.09 & 0.1036 \\
\hline Pure error & & 0.066 & 4 & 0.017 & & & \\
\hline Cor total & & 13.70 & 16 & & & & \\
\hline $\begin{array}{l}\text { Standard } \\
\text { deviation }\end{array}$ & Mean & C.V.\% & Press & $\mathrm{R}^{2}$ & $\mathrm{R}_{\mathrm{Adj}}^{2}$ & $\mathrm{R}_{\text {Pred }}^{2}$ & $\begin{array}{l}\text { Adequate } \\
\text { precision }\end{array}$ \\
\hline 0.20 & 4.85 & 4.04 & 4.40 & 0.9804 & 0.9551 & 0.7557 & 16.347 \\
\hline
\end{tabular}

Note: BBD = Box-Behnken Design

The predicted optimum condition for IPTS yield was obtained: extraction temperature of $86.6^{\circ} \mathrm{C}$, extraction time of $2.23 \mathrm{~h}$ and water:raw material ratio of $10.77 \mathrm{~mL} / \mathrm{g}$. And the theoretical highest LPTS yield was $6.10 \%$. Verificatory experiments were carried out at the modified conditions. The average yield of LPTS obtained from real experiments is $6.08 \%$, which demonstrated the validation of the RSM model.

\section{Cell viability}

The results of MTT assay are shown in Figure 2. It can be seen that $\mathrm{H} 9 \mathrm{c} 2$ cell viability was significantly reduced after $\mathrm{H}_{2} \mathrm{O}_{2}$ treatment, when compared to the normal H9c2 cells $(p<0.01)$. However, the cell viability was significantly increased after IPTS treatment $(200,400,600$ and $800 \mu \mathrm{g} / \mathrm{mL}$ ), when compared to the $\mathrm{H} 9 \mathrm{c} 2$ cells treated with $\mathrm{H}_{2} \mathrm{O}_{2}(p<0.05, p<0.01, p<$ $0.01, p<0.01$, respectively). These results clearly demonstrate that IPTS enhanced the viability of $\mathrm{H}_{2} \mathrm{O}_{2}$ treated cardiomyocytes.

\section{Changes in LDH and CK activities}

The results in Figure 3 show that the LDH and CK contents of H9c2 cells exposed to $\mathrm{H}_{2} \mathrm{O}_{2}$ increased significantly $(p<0.01)$, when compared with normal cells. After treating with IPTS at dose of 200,400 and $800 \mu \mathrm{g} / \mathrm{mL}$, the contents of $\mathrm{LDH}$ and $\mathrm{CK}$ were significantly decreased $(p<0.01, p<0.01, p<0.01$, respectively), relative to the control group. Therefore, the results indicate that LPTS reduces the levels of $\mathrm{LDH}$ and $\mathrm{CK}$ from cytoplasm of $\mathrm{H}_{2} \mathrm{O}_{2}$-induced.

\section{SOD, CAT and MDA levels}

The effects of IPTS on the SOD, CAT and MDA levels in $\mathrm{H}_{2} \mathrm{O}_{2}$-exposed $\mathrm{H} 9 \mathrm{c} 2$ cells are presented on Table 3. After $\mathrm{H}_{2} \mathrm{O}_{2}$ stimulation, the experiment levels of SOD and CAT in H9c2 cells significantly decreased $(p<0.01)$, whereas the MDA level was sharply increased $(p<0.01)$, when compared to normal H9c2 cells. Interestingly, IPTS increased the levels of SOD and CAT $(p<0.01)$ in the H9c2 cells and significantly decreased MDA levels, relative to control group.

\section{Effect of IPTS on apoptosis-related proteins}

The results of expressions of apoptosis related proteins are shown in Figure 4. It can be seen that the expressions of caspase-3 and Bax were significantly up-regulated in $\mathrm{H} 9 \mathrm{c} 2$ cells treated with $\mathrm{H}_{2} \mathrm{O}_{2}$, whereas the expression of $\mathrm{Bcl}-2$ was down-regulated, relative to normal group. However, IPTS at dose of 200, 400 and 800 $\mu \mathrm{g} / \mathrm{mL}$ brought about significant down-regulation of the expressions of caspase- 3 and Bax in H9c2 cells $(p<0.01)$, while significantly up-regulating the expression $\mathrm{Bcl}-2(\mathrm{p}<0.05)$, relative to the control group.

\section{DISCUSSION}

Cardiovascular diseases have become one of the major causes of death all over world [11]. Myocardial infarction leads to myocardial ischemia and even irreversible myocardial necrosis if blood supply is not timely restored $[11,12]$. 

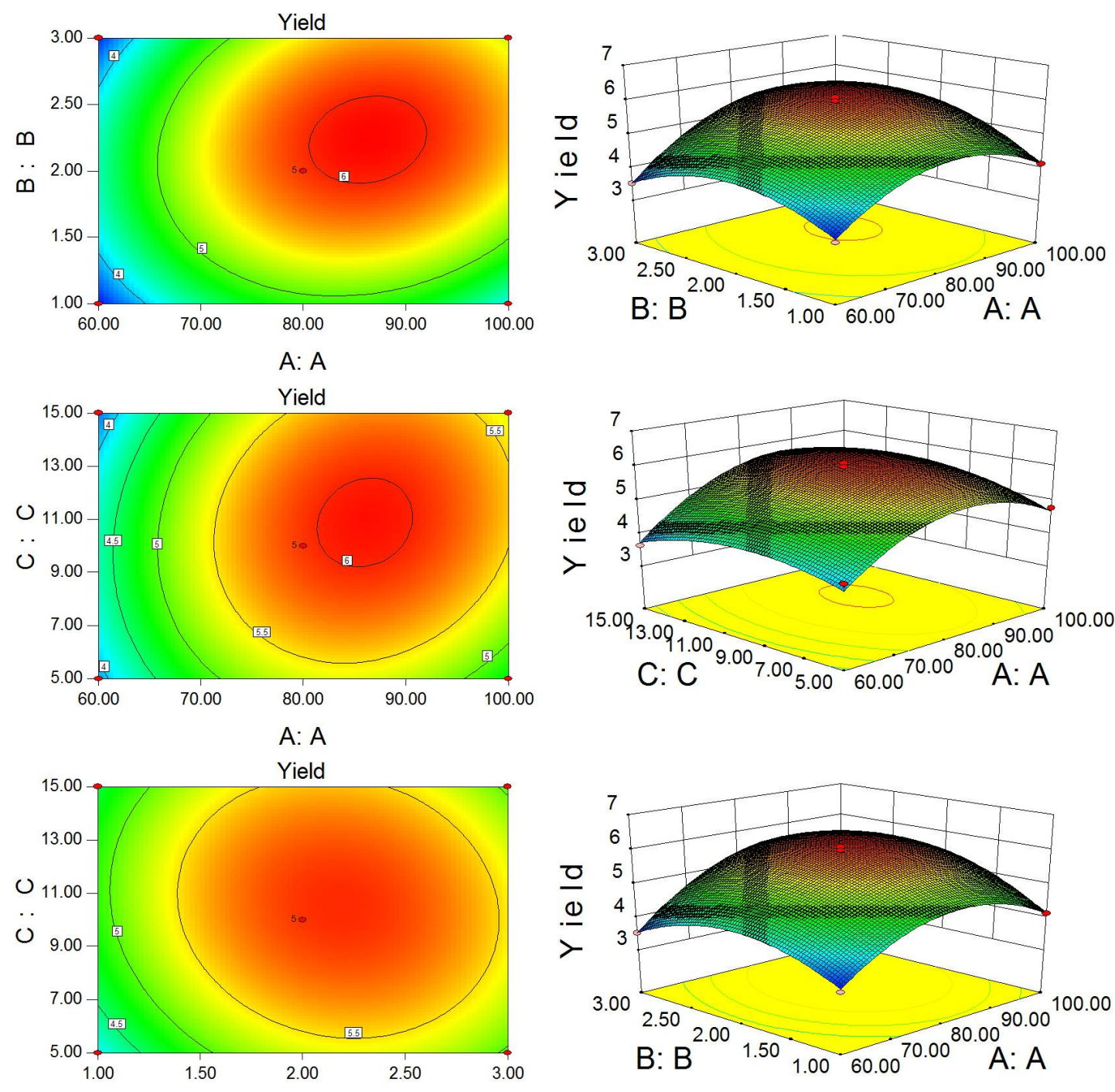

B: B

Figure 1: Results from response surface methodology

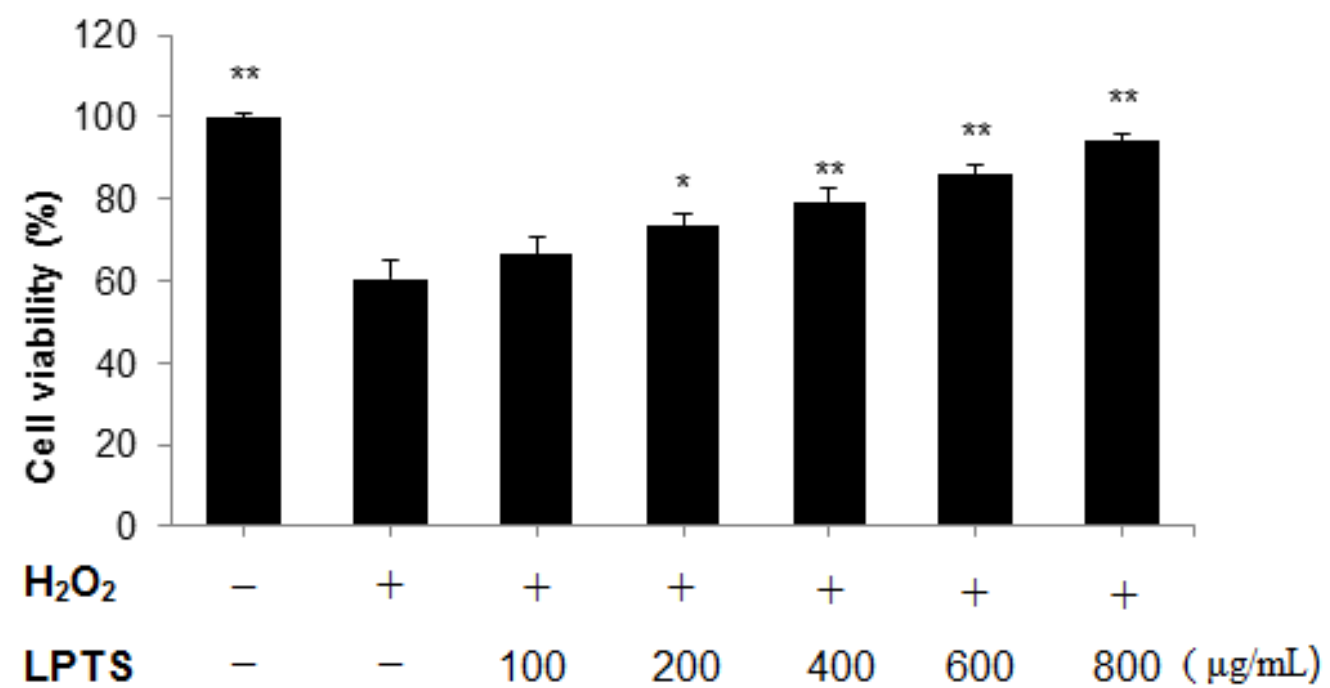

Figure 2: Effect of LPTS on the cell viability rate of $\mathrm{H}_{2} \mathrm{O}_{2}$ stimulated $\mathrm{H} 9 \mathrm{c} 2$ cells. Data are expressed as mean \pm $\mathrm{SD}(\mathrm{n}=6) ;{ }^{*} p<0.05,{ }^{* *} p<0.01$, vs control group 

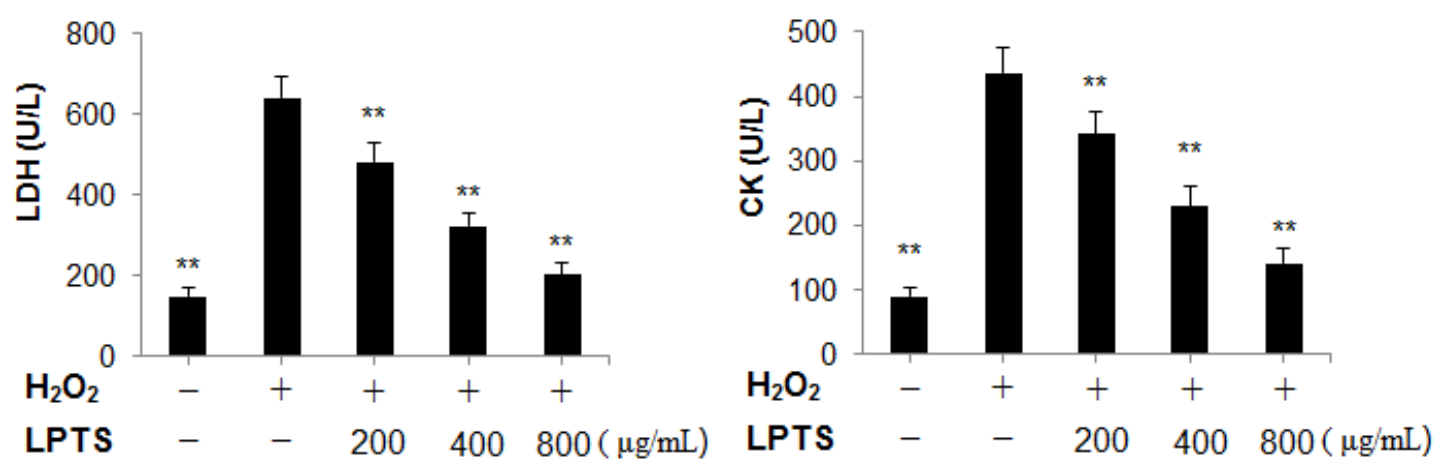

Figure 3: Effect of LPTS on LDH and CK contents in $\mathrm{H}_{2} \mathrm{O}_{2}$ stimulated $\mathrm{H} 9 \mathrm{c} 2$ cells. Data are expressed as Mean \pm $\mathrm{SD}(\mathrm{n}=6) ;{ }^{*} p<0.05,{ }^{* *} p<0.01$, vs control group

Table 3: Effect of LPTS on SOD, CAT and MDA in $\mathrm{H}_{2} \mathrm{O}_{2}$ stimulated $\mathrm{H} 9 \mathrm{c} 2$ cells

\begin{tabular}{|c|c|c|c|}
\hline Group & SOD/U/mg & $\mathrm{CAT} / \mathrm{U} / \mathrm{mg}$ & MDA/ $\mu \mathrm{mol} / \mathrm{g}$ \\
\hline Normal & $97.39 \pm 9.54^{* *}$ & $70.17 \pm 6.47^{\star \star}$ & $14.93 \pm 1.54^{* *}$ \\
\hline Control & $46.29 \pm 6.21$ & $21.05 \pm 4.06$ & $35.21 \pm 3.18$ \\
\hline $200 \mu \mathrm{g} / \mathrm{mL}$ & $63.12 \pm 7.06^{* *}$ & $24.18 \pm 4.63$ & $26.67 \pm 3.03^{*}$ \\
\hline $400 \mu \mathrm{g} / \mathrm{mL}$ & $82.08 \pm 8.92^{\star *}$ & $47.93 \pm 5.54^{\star \star}$ & $19.33 \pm 2.16^{\star \star}$ \\
\hline $800 \mu \mathrm{q} / \mathrm{mL}$ & $96.83 \pm 10.02^{* *}$ & $62.53 \pm 6.72^{* *}$ & $15.64 \pm 1.31^{* *}$ \\
\hline
\end{tabular}
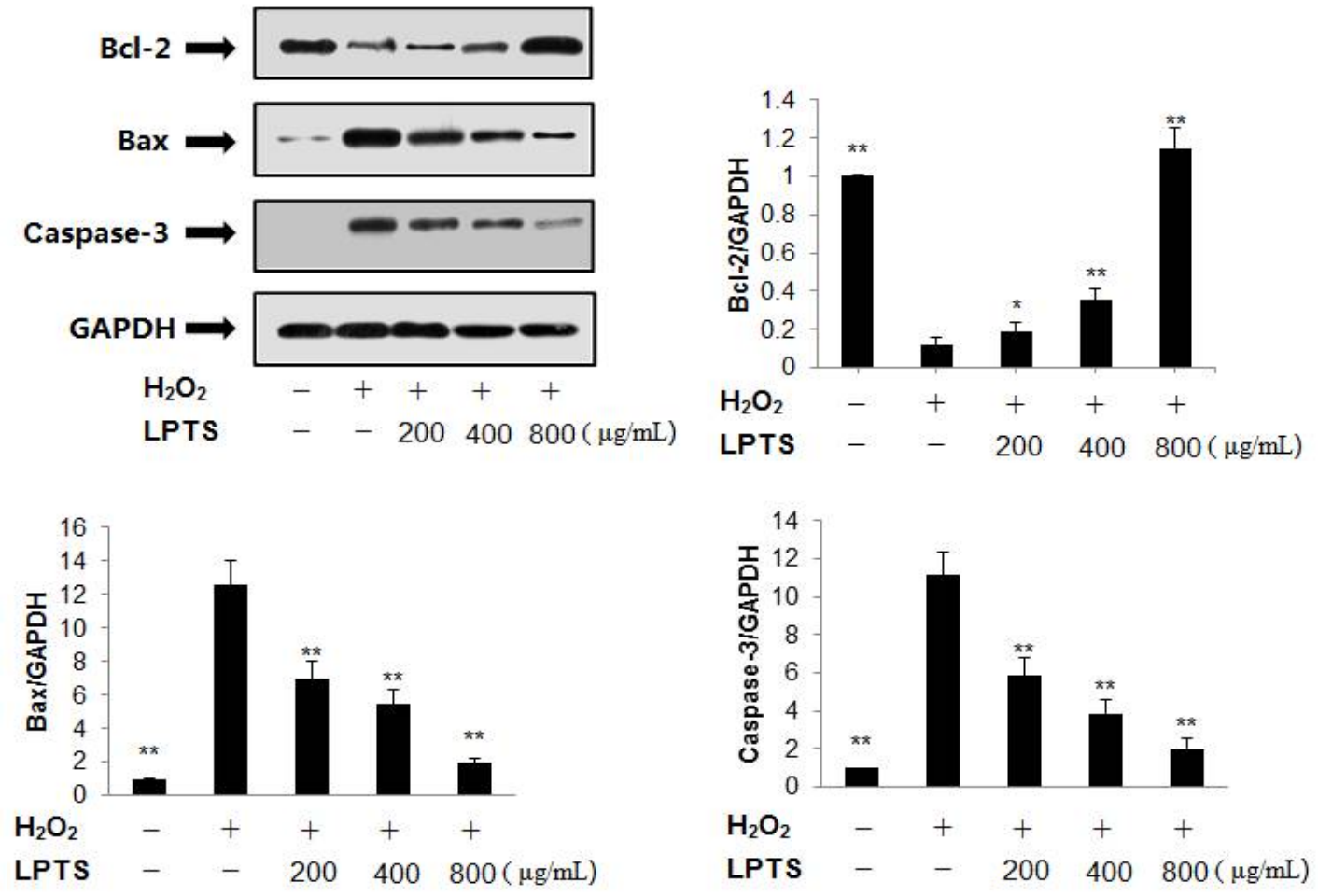

Figure 4: Effect of LPTS on expressions of Caspase-3, Bcl-2, and Bax in $\mathrm{H}_{2} \mathrm{O}_{2}$ stimulated $\mathrm{H} 9 \mathrm{c} 2$ cells. Data are expressed as mean \pm SD $(n=6) ;{ }^{*} p<0.05,{ }^{* *} p<0.01$, vs control group

It has been reported that myocardial ischemia results from the imbalance between the supply of oxygen to the heart and oxygen demand by the heart $[13,14]$. In addition, oxidative stress leads to over-production of oxygen free radicals, which can induce cell apoptosis by damaging cell membrane and enzymes [2]. Hydrogen peroxide $\left(\mathrm{H}_{2} \mathrm{O}_{2}\right)$ and hydroxyl radical $\left(\mathrm{OH}^{\circ}\right)$ enhance intracellular oxidative stress and eventually lead to cell apoptosis and necrosis [15]. $\mathrm{H}_{2} \mathrm{O}_{2}$ may also induce the generation of ROS at mitochondria. The myocardial apoptosis model of 
$\mathrm{H} 2 \mathrm{O} 2$-treated $\mathrm{H} 9 \mathrm{c} 2$ cell line is a convenient model for studying the molecular mechanisms of myocardial ischemic injury. The results of the present investigation demonstrated that LPTS alleviates the $\mathrm{H}_{2} \mathrm{O}_{2}$-induced myocardial apoptosis. In addition, LPTS also decreases the contents of $\mathrm{CK}$ and LDH from cytoplasm.

MDA, one of the main end products of lipid peroxidation, is reported to be used as an indicator of tissue damages. CAT and SOD are the important anti-oxidative enzymes, and commonly considered as the antioxidant defense system in body which plays crucial roles in suppression of oxidative stress [17]. The present results demonstrated that LPTS could increase the CAT and SOD levels in $\mathrm{H}_{2} \mathrm{O}_{2}$ induced $\mathrm{H} 9 \mathrm{c} 2$ cell, whereas the MDA level decreased. The results above showed that LPTS inhibits the oxidative stress level in $\mathrm{H} 9 \mathrm{c} 2$ cell induced by $\mathrm{H}_{2} \mathrm{O}_{2}$.

Caspase proteins, a group of aspartate specific cysteine proteases, play key roles in regulating apoptosis induced by different stimuli. Caspase-3 is the most important effect or in the apoptotic process [18]. Bax is the pro-apoptotic protein, which can translocate to the mitochondria [19]. In contrast, Bcl-2 is an anti-apoptotic protein, which inhibits apoptosis by protecting mitochondrial function [20]. In the present investigation, IPTS down-regulated the levels of caspase-3 and Bax, and up-regulated the expression of $\mathrm{Bcl}-2$. This demonstrated that IPTS can protect myocardial cells from mitochondria-mediated intrinsic apoptosis.

\section{CONCLUSION}

The results of this study demonstrate that the total saponins from Ilex pubescens Hook. (IPTS) exert protective effects of the LPTS on myocardial cells and is a potential new drug for the management of cardiovascular diseases. The mechanism involved in this protective effect might be related to the inhibition of oxidative stress and mitochondria-mediated intrinsic apoptosis

\section{DECLARATIONS}

\section{Acknowledgement}

This work was supported by Beijing nature science foundation (no. 7122171).

\section{Conflict of Interest}

No conflict of interest associated with this work.

\section{Contribution of Authors}

The authors declare that this work was done by the authors named in this article and all liabilities pertaining to claims relating to the content of this article will be borne by them.

\section{Open Access}

This is an Open Access article that uses a funding model which does not charge readers or their institutions for access and distributed under the terms of the Creative Commons Attribution License (http://creativecommons.org/licenses/by/ 4.0) and the Budapest Open Access Initiative (http://www.budapestopenaccessinitiative.org/rea d), which permit unrestricted use, distribution, and reproduction in any medium, provided the original work is properly credited.

\section{REFERENCES}

1. Yi L, Chen $C Y$, Jin X, Mi MT, Chang H, Ling WH, Zhu JD, Zhang QY, Zhang T, Yu B. Structure-activity relationship of anthocyanin phytochemicals in inhibiting oxidizedstress injury of vascular endothelial cells. Acta Acad Med Milit Tertiae 2009; 31(21): 2046-2049.

2. Halliwell B, Gutteridge JM. Free radicals in biology and medicine. Oxford: Clarendon Press, 1989; $p 121051$.

3. Bryant J, Picot J, Levitt G, Sullivan I, Baxter L, Clegg A. Cardioprotection against the toxic effects of anthracyclines given to children with cancer: a systematic review. Health Technol Assess 2007; 11(27): 1-84.

4. Ghorbani A, Sadeghnia HR, Asadpour E. Mechanism of protective effectof lettuce against glucose/serum deprivation-induced neurotoxicity. Nutr Neurosci 2015; 18(3): 103-109.

5. Nanjing University of Chinese Medicine. Great Dictionary of Chinese Medicine. Shanghai: Shanghai science and Technol Press, 2006; $p 608$.

6. Jiang YP, Feng $F$, Xie N, Chen L, Zhu MX. Chemical constituents from the root of llex pubescens Hook. Pharmaceut Clin Res 2008; 16(3): 163-165.

7. Zhou Y, Xiong TQ, Lin CZ, Zhao ZX, Qin CY, Cao Y. Researches on Preparation and pharmacological activity of ilex saponin A1fromtheroot of llex pubescens Hook. J Chin Med Mater 2011; 34(5): 765-767.

8. Yin WQ, Zhou ZL, Zhou JM, Meng J, Fu CY. Researches on extraction, purification and identification of total saponins from the root of llex pubescens Hook. J Chin Med Mater 2007; 30 (9): 1153-1155.

9. Wu LS, Jia M, Chen L, Zhu B, Dong HX, Si JP, Peng W, Han T. Cytotoxic and Antifungal Constituents Isolated from the Metabolites of Endophytic Fungus DO14 from Dendrobium officinale. Molecules 2016; 21: 14, doi: 10.3390/molecules21010014. 
10. Zhang JW, Min DY, Zhou Y, Yang KC, Yu X, Chen DB. Protective effects of lycopene on $\mathrm{H} 2 \mathrm{O} 2$ induced oxidative stress in neonatal rat cardiomyocytes. Chin $\mathrm{J}$ Exp Trad Med Formul 2014; 20: 160-164.

11. Reshma PL, Sainu NS, Mathew AK, Raghua KG. Mitochondrial dysfunction in H9c2 cells during ischemia and amelioration with Tribulusterrestris L.Life Sci 2016; 152: $220-230$.

12. Rezaee MA, Mohammadpour AH, Imenshahidi $M$, Mahmoudi M, Sankian M, Tsarouhas K, Tsakalof A, Tsatsakis AM, Moallem SA. Protective effect of erythropoietin on myocardial apoptosis in rats exposed to carbon monoxide. Life Sci 2016; 148: 118-124.

13. Zhang JW, Min DY, Zhou Y, Yang KC, Yu X, Chen DB. Protective effects of lycopene on $\mathrm{H} 2 \mathrm{O} 2$ induced oxidative stress in neonatal rat cardiomyocytes. Chin J Exp Trad Med Formul 2014; 20: 160-164.

14. Han MM, Wang WF, Liu MY, Li DS, Zhou B, Yu YH, Ren GP. FGF-21 protects H9c2 cardiomyoblasts against hydrogen peroxide induced oxidative stress injury. Acta Pharm Sin 2014; 49: 470-475.

15. Ilavenil S, Kim DH, Jeong YI, Arasu MV, Vijayakumar M, Prabhu PN, Srigopalram S, Choi KC. Trigonelline protects the cardiocyte from hydrogen peroxide induced apoptosis in H9c2 cells. Asian Pac J Trop Med 2015; 8(4): 263-268.
16. Jovanović $S$, Ballantyne $T, D u Q$, Blagojević $M$, Jovanović A. Phenylephrine preconditioning in embryonic heart H9c2 cells is mediated by up-regulation of SUR2B/Kir6.2: A first evidence for functional role of SUR2B in sarcolemmal KATP channels and cardioprotection. Int J Biochem Cell Biol 2016; 70: 2328.

17. Peng W, Hu C, Shu Z, Han T, Qin L, Zheng C. Antitumor activity of tatariside $F$ isolated from roots of Fagopyrum tataricum (L.) Gaerth against H22 hepatocellular carcinoma via up-regulation of p53.Phytomed 2015; 22 : 730-736.

18. Shan H, Yan R, Diao J, Lin L, Wang S, Zhang M, Zhang $R$, Wei J. Involvement of caspases and their upstream regulators in myocardial apoptosis in a rat model of selenium deficiency-induced dilated cardiomyopathy. $J$ Trace Elem Med Biol 2015; 31: 85-91.

19. Li L, Zhou Y, Li Y, Wang L, Sun L, Zhou L, Arai H, Qi Y, $\mathrm{Xu} Y$. Aqueous extract of Cortex Dictamni protects H9c2 cardiomyocytes from hypoxia/reoxygenation-induced oxidative stress and apoptosis byPI3K/Akt signaling pathway. Biomed Pharmacother 2017; 89: 233-244.

20. Guo X, Cao W, Yao J, Yuan Y, Hong Y, Wang X, Xing J. Cardioprotective effects of tilianin in rat myocardial ischemia-reperfusion injury. Mol Med Rep 2015; 11 : 2227-2233. 